\title{
PENGARUH BIMBINGAN KELOMPOK DENGAN TEKNIK ROLE PLAY TERHADAP KECENDERUNGAN PERILAKU AGRESIF SISWA KELAS VIII-E SMP NEGERI 1 BARAT KABUPATEN MAGETAN
}

\author{
Eria Suntari *) \\ Diana Ariswanti Triningtyas **)
}

\begin{abstract}
Abstrak
Tujuan penelitian ini adalah untuk mengetahui pengaruh bimbingan kelompok dengan teknik role play terhadap kecenderungan perilaku agresif siswa kelas VIII E SMP Negeri 1 Barat Kabupaten Magetan.

Penelitian ini dilakukan dengan menggunakan metode eksperimen dengan desain One-Group Pretest-Posttest Design. Bentuk eksperimen yang dilakukan dalam penelitian ini adalah dengan menyampaikan bimbingan kelompok dengan teknik role play untuk mengatasi perilaku agresif pada siswa kelas VIII-E SMP Negeri 1 Barat Kabupaten Magetan. Populasi dalam penelitian ini adalah siswa kelas VIII-E SMP Negeri 1 Barat Kabupaten Magetan yang terindikasi memiliki tingkat kecenderungan perilaku agresif yang tinggi dengan jumlah 34 siswa. Sampel penelitian ini adalah 30\% dari siswa kelas VIII-E SMP Negeri 1 Kabupaten Magetan yang memiliki kecenderungan perilaku agresif yang tinggi. Teknik pengambilan sampel dalam penelitian ini adalah teknik purposive sampling. Data yang digunakan dalam penelitian ini dikumpulkan dengan menggunakan teknik angket yang disusun sendiri oleh peneliti. Analisis data dalam penelitian ini menggunakan uji $t$-score.

Berdasarkan hasil analisis data penelitian, diperoleh hasil sebagai berikut: harga t-hitung ( $t$-score) sebesar 6,885. Untuk mengetahui apakah harga t-hitung sebesar 6,885 tersebut signifikan atau tidak signifikan, maka perlu dikonsultasikan dengan harga t-tabel. Harga t-tabel untuk $\mathrm{N}=10$ dan derajad bebas $(\mathrm{d} . \mathrm{b})=1$ pada taraf signifikansi sebesar 5\%, diperoleh bilangan 2,228. Dengan demikian maka harga t-hitung lebih besar dibandingkan dengan harga ttabel (signifikan/TS=5\%). Simpulan penelitian ini adalah bimbingan kelompok dengan teknik role play dapat mengurangi kecenderungan perilaku agresif siswa kelas VIII E SMP Negeri 1 Barat Kabupaten Magetan.
\end{abstract}

Kata Kunci: Bimbingan Kelompok, Teknik Role Play, kecenderungan Perilaku Agresif.

* Eria Suntari adalah Mahasiswa Program Studi Bimbingan dan Konseling Fakultas Ilmu Pendidikan IKIP PGRI MADIUN.

** Diana Ariswanti Triningtyas adalah Dosen Program Studi Bimbingan dan Konseling Fakultas Ilmu Pendidikan IKIP PGRI MADIUN. 


\section{A. Pendahuluan}

Pada siswa Sekolah Menengah Pertama berusia 12 tahun sampai 15 tahun. Mereka membutuhkan bimbingan dan arahan dari pihak keluarga dan sekolah agar mereka dapat tumbuh dan berkembang secara optimal. Siswa sekolah menengah pertama biasanya merupakan remaja yang memiliki karateristik yang berbeda dengan anak-anak. Dalam tugas perkembangannya pada usia remaja salah satunya siswa mampu mengendalikan diri atas dasar prinsip atau falsafah hidup.

Di dalam kehidupan sehari-hari siswa menyadari bahwa perilakunya akan menimbulkan akibat. Perilaku yang sesuai dengan keinginan dan harapan siswa akan menimbulkan akibat yang positif. Bilamana keinginan dan harapan tidak sesuai dengan kenyataan, maka akan menimbulkan perilaku agresif. Bentuk perilaku agresif negatif muncul dikarenakan kegagalan dalam usahanya yang akan diekspresikan dengan kemarahan, emosi yang menggebu-gebu, bertindak sadis, dan usaha untuk merugikan serta menyakiti orang lain. Sebagaimana diungkapkan Berkowitz dan Myers (dalam Siddiqah, 2010) perilaku agresif diartikan sebagai tindakan yang dimaksudkan untuk melukai atau menyakiti orang lain, baik fisik maupun psikis.

Bahkan banyak disaksikan di media massa baik cetak maupun elektronik. Semakin banyak terjadi kasus tawuran antar pelajar. Hal ini terlihat pada sekolah di Jakarta yaitu SMPN 42 Pademangan, Jakarta Utara yang sedang membawa celurit dan tongkat golf. Siswa tersebut ditangkap saat hendak membantu temannya yang sedang tawuran di Jalan Mangga Dua, Jakarta Utara (dalam Liputan 6.com, tanggal 31 Oktober 2014 pukul 02:21 WIB).

Selain itu ada juga tawuran antar pelajar SMP yang berujung fatal sampai tewas karena menderita luka bacok akibat sabetan senjata tajam. Tawuran bermula ketika korban bersama tujuh temannya tiba-tiba diserang oleh pelajar SMP sekolah lain di depan Kantor Desa Cibatok, Jalan Raya 
Cibatok, Kecamatan Cibungbulang, Kabupaten Bogor (dalam Tempo. Co, tanggal 20 November 2013 pukul 18:37 WIB). Fenomena semakin meningkatnya perilaku agresif di kalangan siswa pada jenjang pendidikan SMP. Siswa berani untuk melakukan apapun agar siswa bisa mendapatkan sesuatu yang menjadi keinginannya bahkan siswa sampai menyakiti orang lain. Aksi-aksi kekerasan tersebut dapat terjadi dimana saja., seperti di jalanan dan di sekolah-sekolah. Aksi tersebut berupa kekerasan verbal (mencaci maki) maupun kekerasan fisik (memukul dan meninju), yang berakibat akan adanya balas dendam dan kematian.

Perkelahian atau tawuran antar siswa tersebut bisa terjadi dikarenakan permasalahan kelompok. Tanpa berpikir panjang siswa yang sedang emosi, langsung meluapkan amarahnya dengan perkelahian atau tawuran. Bahkan yang ada pada pikirannya hanyalah menyakiti dan menyiksa siswa lain mereka anggap musuh atau menjatuhkan mereka. Siswa yang sering berperilaku agresif biasanya mereka kurang mampu memahami keanekaragaman pandangan, budaya, dan tingkat ekonomi. Bahkan mereka juga tergolong orang yang mudah putus asa, melarikan diri dari masalah, menyalahkan orang atau pihak lain.

Tidak menutup kemungkinan disekolah pun juga bisa menjadi tempat yang menakutkan bagi siswa. Ancaman ini dapat berupa tindak kekerasan baik dari teman sebaya, kakak kelas, bahkan guru sekalipun. Ejekan, hinaan dan ancaman merupakan pancingan yang jitu terhadap amarah yang akan mengarah pada perilaku agresif. Hal tersebut sangatlah merugikan banyak pihak dan memberikan dampak yang buruk.

Dengan adanya fenomena-fenomena dan dampak-dampak mengenai kecenderungan perilaku agresif, dan mengingat pentingnya mengurangi perilaku tersebut, salah satu cara untuk mengurangi kecenderungan perilaku agresif adalah dengan memberikan layanan Bimbingan Kelompok. Dalam pelaksanaannya kegiatan bimbingan kelompok dapat digunakan untuk mengatasi siswa yang memiliki masalah yang relatif sama. 
Menurut Romlah (2013: 3) bimbingan kelompok adalah pemberian bantuan yang diberikan pada individu dalam situasi kelompok. Bimbingan kelompok ditujukan untuk mencegah timbulnya masalah pada siswa dan mengembangkan potensi siswa.

Di dalam pelaksanaan bimbingan kelompok digunakan sebuah teknik salah satunya bermain peran atau role play. Sudjana (2005: 134) menyatakan teknik bermain peran adalah teknik kegiatan pembelajaran yang menekankan pada kemampuan penampilan peserta didik untuk memerankan status dan fungsi pihak-pihak lain yang terdapat pada kehidupan nyata.

Hal ini diperkuat oleh pendapat Calhoun et al., (2009: 329) melalui bermain peran diharapkan siswa dapat mengeksplorasi perasaan siswa, mentransfer dan mewujudkan pandangan mengenai perilaku, nilai, dan persepsi siswa, mengembangkan skill pemecahan masalah dan tingkah laku dan mengeksplorasi materi pelajaran dengan cara yang berbeda. Bermain peran juga digunakan untuk mendengarkan dan memecahkan masalah. Bahkan interaksi saat bermain peran dalam praktek sangat efektif untuk mengajarkan keterampilan pada siswa.

Berdasarkan uraian di atas, peneliti tertarik dengan judul "Pengaruh Bimbingan Kelompok dengan Teknik Role Play terhadap Kecenderungan Perilaku Agresif Siswa Kelas VIII E SMP Negeri 1 Barat Kabupaten Magetan”.

\section{B. Kajian Pustaka}

\section{Bimbingan Kelompok}

\section{a. Pengertian Bimbingan Kelompok}

Kusmawati dan Sukardi (2008) berpendapat bahwa bimbingan kelompok yaitu layanan bimbingan dan konseling yang memungkinkan sejumlah peserta didik atau konseli secara bersama-sama melalui dinamika kelompok memperoleh berbagai bahan dari narasumber tertentu, terutama dari guru pembimbing atau konselor, dan atau membahas secara bersama-sama pokok 
bahasan (topic) tertentu yang berguna untuk menunjang pemahaman dan kehidupannya sehari-hari dan/atau untuk perkembangan dirinya baik sebagai individu maupun sebagai pelajar, dan untuk pertimbangan dalam pengambilan keputusan dan atau tindakan tertentu.

Menurut Nurihsan (2009) bimbingan kelompok merupakan bantuan terhadap individu yang dilaksanakan dalam situasi kelompok. Bimbingan kelompok dapat berupa penyampaian informasi ataupun aktivitas kelompok membahas masalah-masalah pendidikan, pekerjaan, pribadi, dan sosial.

\section{b. Materi Bimbingan Kelompok}

Tohirin (2011) berpendapat bahwa layanan bimbingan kelompok membahas materi atau topik-topik umum baik tugas maupun topik bebas. Yang dimaksud topik tugas adalah topik atau pokok bahasan yang diberikan oleh pembimbing (pimpinan kelompok) kepada kelompok untuk dibahas. Sedangkan topik bebas adalah suatu topik atau pokok bahasan yang dikemukakan secara bebas oleh anggota kelompok. Secara bergiliran anggota kelompok mengemukakan topik bebas, selanjutnya dipilih mana yang akan dibahas terlebih dahulu dan seterusnya. Topik-topik yang dibahas dalam layanan bimbingan kelompok baik topik bebas maupun tugas dapat mencakup bidang-bidang pengembangan, kepribadian, hubungan sosial, pendidikan, karier, kehidupan berkeluarga, kehidupan beragama.

\section{c. Tujuan Bimbingan Kelompok}

Bennet (dalam Romlah 2013) mengemukakan tujuan bimbingan kelompok yaitu memberikan kesempatan-kesempatan pada siswa belajar hal-hal penting yang berguna bagi pengarahan dirinya yang berkaitan dengan masalah pendidikan, pekerjaan, 
pribadi dan sosial dan memberikan layanan-layanan penyembuhan melalui kegiatan kelompok.

Tohirin (2011) mengemukakan layanan bimbingan kelompok bertujuan untuk pengembangan kemampuan bersosialisasi, khususnya kemampuan berkomunikasi peserta layanan (siswa). Secara khusus layanan bimbingan kelompok bertujuan untuk mendorong pengembangan perasaan, pikiran, persepsi, wawasan, sikap, yang menunjukkan tingkah laku yang lebih efektif, yakni meningkatkan kemampuan berkomunikasi baik verbal maupun non verbal para siswa.

\section{d. Tahap-tahap Bimbingan Kelompok}

Menurut Tohirin (2011) layanan bimbingan kelompok memiliki tahap-tahap sebagai berikut:

1. Perencanaan, yang mencakup kegiatan: a) mengidentifikasi topik yang akan dibahas dalam layanan bimbingan kelompok, b) membentuk kelompok (misalnya hanya 2-3 orang saja) tidak efektif untuk layanan bimbingan kelompok karena kedalaman dan variasi pembahasan menjadi terbatas. Sebaliknya kelompok yang terlalu besar pun tidak efektif, karena akan mengurangi tingkat partisipasi aktif individual dalam kelompok. Kelompok juga kurang efektif apabila jumlah anggotanya melebihi 10 orang. Kelompok yang ideal jumlah anggotanya antara 8-10 orang, c) menyusun jadwal kegiatan, d) menetapkan prosedur layanan, e) menetapkan fasilitas layanan,dan f) menyiapkan kelengkapan adminitrasi.

2. Pelaksanaan, yang mencakup kegiatan: a) mengkomunikasikan rencana layanan bimbingan kelompok, b) mengorganisasikan kegiatan layanan bimbingan kelompok, c) menyelenggarakan layanan bimbingan kelompok melalui tahap-tahap: (a) pembentukan, (b) peralihan, (c) kegiatan, dan (d) pengakhiran. 
3. Evaluasi, yang mencakup, a) menetapkan materi evaluasi (apa yang akan di evaluasi), b) menetapkan prosedur dan standart evaluasi, c) menyusun instrumen evaluasi, d) mengoptimalkan instrumen evaluasi, dan e) mengolah hasil aplikasi instrumen.

4. Analisis hasil evaluasi, yang mencakup kegiatan: 1) menetapkan norma atau standart analisis, 2) melakukan analisis, dan 3) menafsirkan hasil analisis.

5. Tindak Lanjut, yang mencakup: a) menetapkan jenis dan arah tindak lanjut, b) mengkomunikasikan rencana tindak lanjut kepada pihak-pihak yang terkait, dan c) melaksanakan rencana tindak lanjut.

6. Laporan, yang mencakup kegiatan: a) menyusun laporan, b) melaporkan laporan kepada kepala sekolah atau madrasah dan pihak-pihak lain yang terkait, c) mendokumentasikan laporan layanan.

\section{Teknik Role Play}

\section{a. Pengertian Teknik Role Play}

Huda (2013) berpendapat bahwa role play adalah suatu cara penguasaan bahan-bahan pelajaran melalui pengembangan imajinasi dan penghayatan siswa. Sudjana (2005) menyatakan teknik bermain peran adalah teknik kegiatan pembelajaran yang menekankan pada kemampuan penampilan peserta didik untuk memerankan status dan fungsi pihak-pihak lain yang terdapat pada kehidupan nyata.

\section{b. Tujuan Role Play}

Calhoun et al., (2011) menyebutkan secara ringkas tujuan role play adalah mengekplorasi perasaan siswa, mentransfer dan mewujudkan pandangan mengenai perilaku, nilai, dan persepsi siswa, mengeksplorasi materi pelajaran dengan cara yang berbeda. Sudjana (2005) menyebutkan tujuan role play sebagai berikut: 
tujuan penggunaan teknik ini antara lain adalah untuk mengenalkan peran-peran dalam dunia nyata kepada peserta didik. Setelah mereka mengenal peran-peran dalam dunia nyata kepada peserta didik. Setelah mereka mengenal peran-peran tadi maka mereka dapat memahami keunggulan dan kelemahan peran-peran tersebut serta dapat mengajukan alternatif saran atau pendapat untuk mengembangkan peran-peran yang ditampilkan dalam kehidupan sebenarnya.

\section{c. Strategi Role Play}

Huda (2014) menyatakan sintak strategi Role Play dapat dilihat dalam tahap-tahapnya adalah sebagai berikut:

1. Guru menyusun/menyiapkan skenario yang akan ditampilkan.

2. Guru menunjuk beberapa siswa untuk mempelajari skenario dalam waktu beberapa hari sebelum pelaksanaan kegiatan belajar mengajar.

3. Guru membentuk kelompok siswa yang masing-masing beranggotakan 5 orang.

4. Guru memberikan penjelasan tentang kompetensi yang ingin dicapai.

5. Guru memanggil para siswa yang sudah ditunjuk untuk melakukan skenario yang sudah dipersiapkan.

6. Masing-masing siswa mengamati skenario yang diperagakan.

7. Setelah selesai ditampilkan, masing-masing siswa diberikan lembar kerja untuk membahas/memberi penilaian atas penampilan masing-masing kelompok.

8. Masing-masing kelompok menyampaikan hasil kesimpulannya.

9. Guru memberikan kesimpulan dan evaluasi secara umum.

\section{Kecenderungan Perilaku Agresif}

\section{a. Pengertian Kecenderungan Perilaku Agresif}

Kecenderungan adalah kecondongan (hati), kesudian, keinginan (kesukaan) akan: (dalam Kamus Besar Bahasa Indonesia, 
2008). Menurut Berkowitz dkk., (dalam Thalib, 2010) perilaku agresif didefisinikan sebagai perilaku yang secara actual menimbulkan dampak negatif baik secara fisik, psikis, sosial, integritas pribadi, objek atau lingkungan.

Berkowitz dan Myers (dalam Siddiqah, 2010) mengartikan perilaku agresif sebagai tindakan yang dimaksudkan untuk melukai atau menyakiti orang lain, baik fisik maupun psikis (Franzoi, 2003: Anderson \& Huesmann, 2007) yang menimbulkan kerugian atau bahaya bagi orang lain atau merusak milik orang lain.

\section{b. Faktor Penyebab Perilaku Agresif}

Sementara menurut Viemero (dalam Thalib, 2010) faktor perilaku agresif ada 4 yaitu Perilaku agresif orang tua, perilaku agresif pada masa kanak-kanak, kebiasaan nonton TV dengan tema film kekerasan pada masa kanak-kanak, perilaku deliquen pada masa remaja.

\section{c. Bentuk-bentuk Perilaku Agresif}

Medinus dan Johnson (dalam Hudaniah dan Dayakisni, 2009) mengelompokkan agresi menjadi empat kategori, yaitu: Menyerang fisik, yang termasuk di dalamnya adalah memukul, mendorong, meludahi, menendang, mengigit, meninju, memarahi dan merampas, menyerang suatu obyek, yang dimaksudkan disini adalah menyerang benda mati atau binatang, secara verbal atau simbolis, yang termasuk di dalamnya adalah sikap mengancam dan sikap menuntut dan pelanggaran terhadap hak milik atau menyerang daerah orang lain.

\section{d. Strategi Mengurangi Perilaku Agresif}

Menurut Hanurawan (2010) mengemukakan bahwa beberapa startegi untuk mengendalikan dan mengurangi prevelensi perilaku agresif yaitu :

1. Strategi Hukuman 
Sepanjang perjalanan kebudayaab manusia, hampir semua kelompok masyarakat menggunakan hukuman sebagai instrumen utama untuk mengendalikan dan mengurangi perilaku kekerasan dalam diri manusia. Apabila diterapkan dalam cara-cara yang tepat maka hukuman termasuk strategi pengendalian yang efektif terhadap prevalensi timbulnya perilaku agresi dalam masyarakat. Baran dan Byrne (dalam Hanurawan, 2009) mengemukakan bahwa hukuman menjadi instrument di bawah kondisi-kondisi sebagai berikut:

a. Hukuman harus diberikan segera setelah perilaku agresi terjadi

b. Besarnya tingkat hukuman harus setimpal

c. Hukuman harus diberikan setiap kali perilaku agresi timbul.

2. Strategi Katarsis

Pada konteks katarsis itu, partisipasi individu dalam aktivitas katarsis nonagresi ternyata hanya memiliki pengaruh yang bersifat sementara terhadap rangsang emosional. Setelah melewati jangka waktu tertetu, rangsang dan tendensi itu kemudian akan muncul kembali apabila individu itu bertemu secara langsung atau berpikir tentang orang yang sebelumnya menyebabkan dirinya marah atau terangsang melakukan perilaku agresi.

3. Strategi Pengenalan terhadap Model Nonagresi

Pengenalan terhadap model nonagresif dapat mengurangi dan mengendalikan perilaku agresi individu. Dalam penelitian Baron dan Donnerstein (dalam Fattah Hanurawan, 2009) ditemukan bahwa individu yang mengamati perilaku model nonagresif menunjukkan tingkat agresi yang lebih rendah daripada individu yang tidak mengamati perilaku model nonagresif.

4. Strategi Pelatihan Keterampilan Sosial 
Pelatihan keterampilan sosial dapat mengurangi timbulnya perilaku agresi. Sering individu-individu yang karena keterampilan sosialnya rendah menyebabkan mereka melakukan tindakan agresi. Hal itu terjadi karena mereka kurang mampu mengekspresikan atau mengkomunikasikan keinginan pada orang lain, gaya bicara yang kaku, dan tidak sensitive terhadap symbolsimbol emosional orang lain. Ketidakmampuan itu dapat menyebabkan timbulnya frustasi dalam diir mereka. Frustasi itu dalam kesempatan berikutnya dapat menimbulkan perilaku agresi. Melalui pelatihan keterampilan social yang memadai, perilaku agresi dapt dikurangi dalam diri mereka.

\section{Metodologi Penelitan}

Penelitian ini dilakukan di SMP Negeri 1 Barat Kabupaten Magetan, yang beralamat di Jalan Raya Pos Barat Desa Karangsono Kecamatan Barat Kabupaten Magetan. Rancangan penelitian yang digunakan dalam penelitian ini adalah metode penelitian eksperimen. Sugiyono (2012) menjelaskan bahwa metode penelitian eksperimen merupakan metode penelitian yang digunakan untuk mencari pengaruh perlakuan tertentu terhadap hal lain dalam kondisi yang terkendali. Penggunaan metode penelitian eksperimen berfungsi untuk mengetahui pengaruh suatu perlakuan (treatment) terhadap suatu kelompok dengan pengendalian situasi.

Dalam penelitian eksperimen, ada perlakuan (treatment).Adapun bentuk desain eksperimen yang dikembangkan dalam penelitian ini adalah One Group Pretest-Posttest Design.

Selanjutnya, bentuk eksperimen yang dilakukan, yaitu dengan menyampaikan layanan bimbingan kelompok untuk mengatasi tingginya perilaku agresif pada siswa sebagai perlakuan (treatment).

Populasi dalam penelitian ini adalah $30 \%$ dari siswa kelas VIII E SMP Negeri 1 Barat Kabupaten Magetan yang terindikasi memiliki 
tingkat kecenderungan perilaku agresif yang tinggi. Berdasarkan hasil wawancara dengan konselor diketahui bahwa siswa kelas VIII E SMP Negeri 1 Barat Kabupaten Magetan adalah sebanyak 10 siswa.

Teknik pengambilan sampel yang digunakan dalam penelitian ini ini adalah teknik purposive sampling. Menurut Arikunto (2010) sampling purposive adalah "teknik penentuan sampel dengan pertimbangan tertentu". Berdasarkan pertimbangan tersebut, dalam penelitian ini diperoleh sampel yang berjumlah 10 siswa.

Metode pengumpulan data dengan menggunakan angket. Sugiyono (2012) menyatakan bahwa kuesioner merupakan teknik pengumpulan data yang dilakukan dengan cara memberikan seperangkat pertanyaan atau pernyataan tertulis kepada responden untuk dijawabnya. Secara keseluruhan penyusunan angket ini mengacu pada pola Skala Likert (dalam Sugiyono 2012). Angket yang digunakan dalam pengumpulan data dalam penelitian ini apat diuraikan sebagai berikut :1) Kecenderungan Perilaku Agresif yang mencakup mengancam secara fisik atau verbal, melecehkan orang lain (mengejek, berteriak, berkata kasar), cenderung menyerang orang lain, adanya sikap tidak sopan, memaksa untuk memiliki benda-benda orang lain yang bukan haknya. Dari keseleruhan indikator tersebut terdiri dari 20 butir aitem.

Menurut Arikunto (2010) menyatakan bahwa validitas adalah suatu ukuran yang menunjukkan tingkat-tingkat kevalidan atau kesahihan sesuatu instrumen. Untuk pengujian ini digunakan rumus korelasi product moment dengan angka kasar sebagaimana yang dikemukakan oleh Suharsimi Arikunto (2010) sebagai berikut:

$$
\mathrm{r}_{\mathrm{xy}}=\frac{N \Sigma_{x y}-\left(\Sigma_{x}\right)\left(\Sigma_{y}\right)}{x^{2}-\left(\Sigma_{x}\right)^{2} Y\left(N \Sigma_{y^{2}}-\left(\Sigma_{y}\right)^{2}\right\}}
$$

Kriteria: r-hitung kemudian dikonsultasikan dengan r-tabel pada taraf signifikan 5\%. Jika $\mathrm{r}$ hitung > r tabel, item dinyatakan valid. 
Uji Reabilitas dalam penelitian ini dilakukan dengan menggunakan rumus Alpha. Arikunto (2010) berpendapat reliabilitas adalah "dapat dipercaya". Sebuah tes dikatakan reliabel atau dapat dipercaya apabila memberikan hasil yang tetap atau ajeg jika diteskan berkali-kali. Penggunaaan rumus ini didasarkan pada alasan karena skor yang diperoleh bukan 1 dan 0 , tetapi 1 sampai dengan 4 .

$$
\left.\mathrm{r}_{11}=\right)\left(1-\frac{\Sigma \sigma_{b^{2}}}{\sigma_{t}^{2}}\right)
$$

Varians butir

$$
\sigma_{b^{2}}=\frac{\sum x^{2}-\frac{\left(\sum x\right)^{2}}{n}}{n}
$$

Varians total

$$
\sigma_{t^{2}}=\frac{\sum Y^{2}-\frac{\left(\sum Y\right)^{2}}{n}}{n}
$$

Kriteria: Hasil r-hitung kemudian dikonsultasikan dengan taraf signifikansi 5\%. "Jika $\mathrm{r}$ hitung > $(0,6)$, maka instrumen dikatakan reliabel dan jika $\mathrm{r}$ hitung $<(0,6)$, maka instrumen dikatakan tidak reliabel".

Tujuan yang ingin dicapai dalam penelitian ini adalah untuk mengetahui pengaruh layanan bimbingan kelompok dengan teknik role play dapat mengatasi kecenderungan perilaku agresif siswa kelas VIII E Kabupaten Magetan, sedang data yang mendukung untuk mencapai tujuan penelitian ini adalah data yang berskala rasional. Sesuai dengan tujuan penelitian, maka analisis data dalam penelitian ini menggunakan teknik $t$-score, dengan rumus :

$t=\frac{M_{x}-M_{y}}{S D_{b m}}$ 


\section{Hasil Penelitian}

Angket kecenderungan perilaku agresif diuji validitasnya menggunakan rumus product moment dengan kriteria angket yang digunakan nilai $r_{x y}>0,444$. Hasil uji validitas angket kecenderungan perilaku agresif terhadap 20 siswa, dari 20 butir soal angket yang diujikan, terdapat 20 butir yang valid (layak untuk penelitian). Oleh karena itu, butir soal tersebut memenuhi kriteria untuk digunakan dalam mengambil data kecenderungan perilaku agresif.

Angket kecenderungan perilaku agresif sebelum digunakan untuk pengambilan data perilaku agresif diuji reliabilitasnya. Dalam penelitian ini, uji reliabilitas menggunakan rumus Alpha, angket dikatakan reliabel jika $r_{11}>0,6$.Hasil uji coba angket kecenderungan perilaku agresif terhadap 20 siswa diperoleh harga $r_{11}=0,883$. Hal ini artinya angket kecenderungan perilaku agresif dan dapat digunakan untuk mengambil data kecenderungan perilaku agresif.

Berdasarkan hasil analisis data penelitian seperti yang tertera pada lampiran 15, diperoleh hasil sebagai berikut: harga t-hitung (t-score) sebesar 6,885. Untuk mengetahui apakah harga t-hitung sebesar 3,694 tersebut signifikan atau tidak signifikan, maka perlu dikonsultasikan dengan harga t-tabel. Harga t-tabel untuk $\mathrm{N}=10$ dan derajad bebas (d.b) = 1, diperoleh bilangan 2,228, taraf signifikansi sebesar 5\%. Dengan demikian maka harga t-hitung $(6,885)$ lebih besar dibandingkan dengan harga t-tabel ( signifikan/TS=5\%).

Deskriptif data kecenderungan Perilaku agresif Sebelum di beri Perlakuan. Angket dihitung dengan cara manual, hasil penelitian adalah sebagai berikut: dari sampel yang diperoleh dengan jumlah 10 siswa, mean nilai atau rata-rata 46,5 , standart deviasi 8,888 , mode atau nilai yang sering muncul 57, median atau nilai tengah 46, skor maksimal 60 sedangkan skor minimal 33. Selanjutnya,dilakukan penghitungan range (R) dan lebar kelas (i). Rentang kelas = skor batas atas nyata dikurangi skor batas nyata terendah $(60,5-32,5=28)$. Ditentukan lebar kelas $(i)=$ 
7. Jadi $\mathrm{R}$ dalam distribusi frekuensi $=28: 7=4$. Dari langkah-langkah tersebut, diperoleh tabel distribusi frekuensi sebagai berikut:

Tabel 4.1. Distribusi Frekuensi Data Kecenderungan Perilaku Agresif Sebelum Pelaksanaan Layanan Bimbingan Kelompok dengan Teknik Role Play

\begin{tabular}{|c|c|c|c|c|}
\hline No. & $\begin{array}{c}\text { Interval Nilai } \\
(\mathbf{i})\end{array}$ & $\begin{array}{c}\text { Titik Tengah } \\
(\mathbf{X i})\end{array}$ & $\begin{array}{c}\text { Frekuensi } \\
(\mathbf{F})\end{array}$ & $(\mathbf{\% )}$ \\
\hline 1 & $54-60$ & 57 & 3 & $30 \%$ \\
\hline 2 & $47-53$ & 50 & 2 & $20 \%$ \\
\hline 3 & $40-46$ & 43 & 2 & $20 \%$ \\
\hline 4 & $33-49$ & 36 & 3 & $30 \%$ \\
\hline \multicolumn{2}{|c|}{ Total } & & 10 & $100 \%$ \\
\hline
\end{tabular}

Berdasarkan hasil distribusi nilai di atas dapat dibuat grafik sebagai berikut:

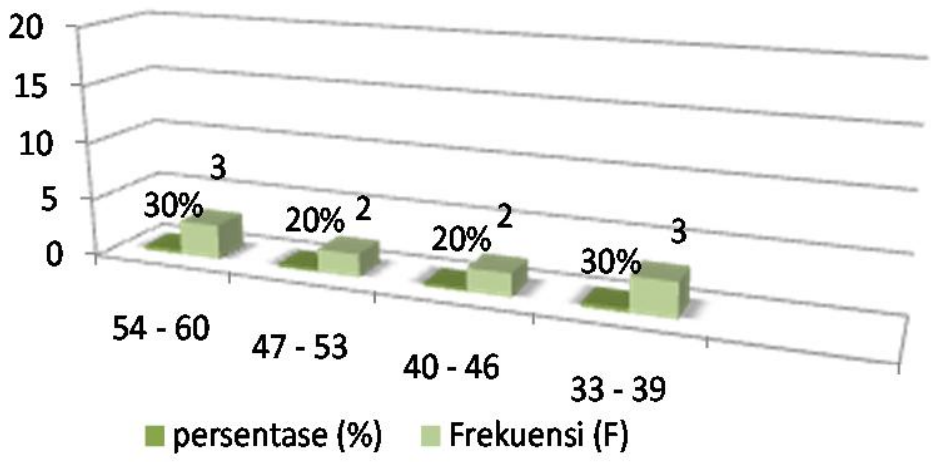

Gambar 4.1. Histogram Kecenderungan Perilaku Agresif Sebelum Pelaksanaan Layanan Bimbingan Kelompok dengan Teknik Role Play

Deskriptif data kecenderungan Perilaku agresif Sesudah di beri perlakuan. Angket dihitung dengan cara manual, hasil penelitian adalah sebagai berikut: dengan sampel yang berjumlah 10 orang, mean nilai atau rata-rata 70,5, standart deviasi 5,507, mode atau nilai yang sering muncul 75 , median atau nilai tengah 72,5, skor maksimal 77 sedangkan skor 
minimal 58. Selanjutnya, dilakukan penghitungan range (R) dan lebar kelas (i). Rentang kelas = skor batas atas nyata dikurangi skor batas nyata terendah $(77,5-57,5=20)$. Ditentukan lebar kelas $(\mathrm{i})=5$. Jadi $\mathrm{R}$ dalam distribusi frekuensi $=20: 5=4$. Dari langkah-langkah tersebut, diperoleh tabel distribusi frekuensi sebagai berikut :

Tabel 4.2. Distribusi Frekuensi Data Kecenderungan Perilaku Agresif Sesudah Pelaksanaan Layanan Bimbingan Kelompok dengan Teknik Role Play

\begin{tabular}{|l|c|c|c|c|}
\hline No. & $\begin{array}{c}\text { Interval Nilai } \\
(\mathbf{i})\end{array}$ & $\begin{array}{c}\text { Titik Tengah } \\
(\mathbf{X i})\end{array}$ & $\begin{array}{c}\text { Frekuensi } \\
(\mathbf{F})\end{array}$ & $(\boldsymbol{\%})$ \\
\hline 1 & $73-77$ & 75 & 5 & $50 \%$ \\
\hline 2 & $68-72$ & 70 & 2 & $20 \%$ \\
\hline 3 & $63-67$ & 65 & 2 & $20 \%$ \\
\hline 4 & $58-62$ & 60 & 1 & $10 \%$ \\
\hline \multicolumn{2}{|l|}{} & & 10 & $100 \%$ \\
\hline
\end{tabular}

Berdasarkan hasil distribusi nilai di atas dapat dibuat grafik sebagai berikut:

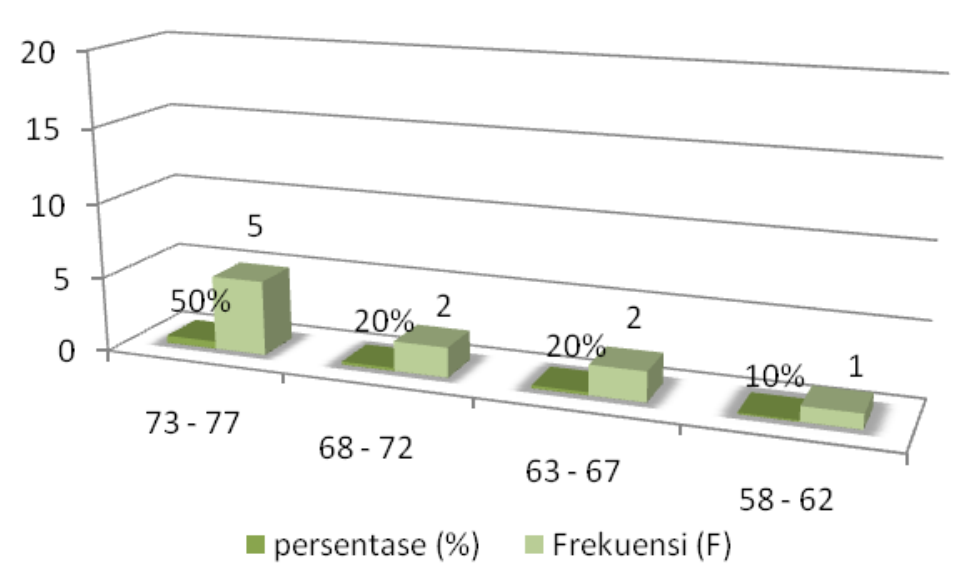

Gambar 4.2. Histogram Kecenderungan perilaku agresif sesudah pelaksanaan layanan bimbingan kelompok dengan teknik role play 


\section{E. Kesimpulan dan Saran}

Berdasarkan analisis data dari penelitian yang telah dilakukan diperoleh kesimpulan bahwa ada pengaruh layanan bimbingan kelompok dengan Teknik Role Play terhadap Kecenderungan Perilaku Agresif Siswa Kelas VIII E SMP Negeri 1 Barat Kabupaten Magetan.

Berdasarkan penelitian diperoleh hasil bahwa ada pengaruh layanan bimbingan kelompok dengan Teknik Role Play terhadap Kecenderungan Perilaku Agresif Siswa Kelas VIII E SMP Negeri 1 Barat Kabupaten Magetan untuk itu berikut dikemukakan beberapa saran yaitu:

1. Bagi sekolah harus dapat mempergunakan hasil penelitian ini sebagai bahan pertimbangan dalam memberikan arahan kepada siswa, khususnya untuk masalah yang berkaitan dengan pelaksanaan kegiatan untuk mengurangi kecenderungan perilaku agresif siswa melalui bimbingan kelompok dengan teknik role play.

2. Kepada para staf guru agar memanfaatkan hasil penelitian ini sebagai data yang sangat berharga, khususnya dalam menyusun program layanan bimbingan di sekolah.

3. Kepada para staf sebaiknya dapat memanfaatkan hasil penelitian tentang cara pelaksanaan bimbingan kelompok dengan menerapkan layanan bimbingan kelompok dengan teknik role play dalam upaya mengatasi kecenderungan perilaku agresif pada siswa.

4. Kepada para siswa, agar memberikan kemudahan dalam mengurangi kecenderungan perilaku agresifnya, sehingga siswa dapat mengembangkan dirinya ke arah yang lebih baik untuk mencapai kesuksesan.

5. Sebagai masukan kepada orang tua agar melaksanakan pengawasan terhadap anak-anaknya selama di rumah serta memberikan nasehat agar anak-anaknya tidak terbiasa berperilaku agresif di manapun berada.

6. Hasil penelitian ini dapat digunakan untuk menambah khasanah ilmu pengetahuan bimbingan dan konseling. 


\section{DAFTAR PUSTAKA}

Arikunto, S. 2010. Prosedur Penelitian : Suatu Pendekatan Praktik. Jakarta Rineka Cipta.

Calhoun, E et al,. Model Of Teaching Model-Model Pembelajaran. Yogyakarta: Pustaka Belajar.

Departemen Pendidikan Nasional.2008. Kamus Besar Bahasa Indonesia Pusat Bahasa. Jakarta: PT. Gramedia Pustaka Umum.

Hadi, S. 2015. Statistik. Yogyakarta : Pustaka Pelajar.

Hanurawan,F. 2010. Psikologi Sosial, Bandung: PT. Remaja Rosdakarya.

http://news.liputan6.com/read/2126996/hendak-bantu-temannya-tawuran-pelajarsmp-diciduk-polisi, Diunduh 22 Maret 2015.

http://www.tempo.co/read/news/2013/11/20/064531161/Tawuran-Pelajar-SMPSatu-Orang-Tewas, Diunduh 22 Maret 2015.

Huda, M. 2014. Model-model Pengajaran dan Pembelajaran. Yogyakarta: Pustaka Belajar.

Hudaniah \& Dayakisni, T. Psikologi Sosial. 2009. Malang: UMM Press.

Kusmawati, N \& Sukardi, Dewa K. 2008. Proses Bimbingan dan Konseling di Sekolah. Jakarta: Rineka Cipta.

Nurihsan, Achmad J. 2009. Bimbingan dan Konseling dalam Berbagai Latar Belakang. Bandung: Refika Aditama.

Romlah, T. 2013. Teori dan Praktek Bimbingan Kelompok. Malang: Universitas Negeri Malang.

Siddiqah, L. 2010. Pencegahan dan Penanganan Perilaku Agresif Remaja Melalui pengelolaan Amarah (Anger Management). Jurnal Psikolog Universitas Gadjah Mada (Online), Volume 37, No 1, (http://.jurnal.psikologi.ugm.ac.id Diunduh 14 Maret 2015).

Sudjana. 2005. Metode dan Teknik Pembelajaran Pertisipatif. Bandung: Fallah Production.

Sugiyono. 2012. Metode Penelitian Pendidikan: Pendekatan Kuantitaif, Kualitatif, dan R\&D. Bandung: Alfabeta.

Thalib, Syamsul B. 2010. Psikologi Pendidikan Berbasis Analisis Empiris Aplikatif. Jakarta: Kencana.

Tohirin. 2007. Bimbingan dan Konseling di Sekolah dan Madrasah. Jakarta: Raja Grafindo Persada. 